\title{
ПОВТОРНА РЕВАСКУЛЯРИЗАЦІЯ РЕЦИДИВУ ХРОНІЧНОЇ АРТЕРІАЛЬНОЇ НЕДОСТАТНОСТІ У ПАЦІЄНТІВ ПІСЛЯ РЕКОНСТРУКЦІї АОРТО/КЛУБОВО- СТЕГНОВОї ЗОНИ
}

Повторна реваскуляризація рецидиву хронічної артеріальної недостатності у пацієнтів після реконструкції аорто/клубово-стегнової зони

І. К. Венгер, С. Я. Костів, М. О. Гусак, Н. І. Герасимюк, А. Р. Вайда, О. Б. Колотило, Д. В. Ковальський

Тернопільський національний медичний університет імені І. Я. Горбачевського МОЗ України

Резюме. Основною причиною розвитку ускладнень пізнього післяопераційного періоду в пацієнтів після реконструктивних втручань на магістральних артеріях нижніх кінцівок вважається прогресування некорегованого атеросклеротичного процесу. До найбільш частих ускладнень віддаленого післяопераційного періоду відносять тромбози артерій та шунтів, несправжні аневризми анастомозів, інфекційні ускладнення із поширенням процесу на судинні експлантати. Поряд з цим, діагностується ряд віддалених ускладнень, що розвиваються у результаті незастосування деяких способів та методів оперативного втручання у складі реконструктивних операцій на магістральних артеріях.

Мета дослідження - покращити результати повторної реваскуляризації артеріального русла нижніх кінцівок у пацієнтів із рецидивом хронічної артеріальної недостатності у віддаленому післяопераційному періоді після реконструкції аорто/клубово-стегнової зони.

Матеріали і методи. Протягом 2006-2019 рр. простежено віддалені результати хірургічного лікування 522 хворих. Оперативне втручання проведено 353 пацієнтам, з яких у 260 мало місце порушення кровотоку по стегно-підколінному сегменті. У вказані терміни прооперовано 159 пацієнтів із приводу оклюзивно-стенотичного ураження клубово-стегнової зони, з яких у 94 мало місце порушення кровоплину по стегно-підколінному артеріальному руслі. На час первинного хірургічного втручання у 228 пацієнтів діагностовано хронічну артеріальну недостатність (ХАН) IIIA cm. (за класифрікацією R. Fontaine з урахуванням критеріїв $\epsilon_{в-}$ ропейської робочої групи (1992)), у 189 - ХКІНК IIІБ-IV cm., у 98 - ХАН ІІБ cm. У 92 (17,6 \%) хворих був гемодинамічно значимий стеноз екстракраніальних артерій, з них 75 проведено оперативне втручання на судинах шиї в умовах хірургічного лікування атеросклеротичного ураження аорто/клубово-стегно-підколінного артеріального русла.

@I. К. Венгер та ін., 2019
Repeated revascularization of chronic arterial failure recurrence in patients after aorto/iliofemoral region reconstruction

I. K. Venher, S. Ya. Kostiv, M. O. Husak, N. I. Herasymiuk, A. R. Vaida, O. B. Kolotylo, D. V. Kovalskyi I. Horbachevsky Ternopil National Medical University e-mail: husak@tdmu.edu.ua

Summary. The main reason for the development of complications in late postoperative period in patients after reconstructive operations on major arteries of the lower extremities is considered uncontrolled the progression of the atherosclerotic process. The most frequent complications of the remote postoperative period include thrombosis of arteries and bypass grafts, a false aneurysm of anastomoses, infectious complications by spread of the vascular Explant. Along with this, identifying a number of long-term complications, developing as a result of not applying some of the techniques and methods of surgical intervention in the composition of the reconstructive operations on trunk arteries.

The aim of the study - to improve the results of repeated revascularization of the arterial bed of the lower extremities in patients with relapse of chronic arterial insufficiency in the late postoperative period after aorto/iliofemoral region.

Materials and Methods. The results of surgical treatment of 522 patients were monitored during 2006-2019. 353 patients were subjected to surgery, 260 of whom had disturbed blood flow in the thigh-popliteal segment. 159 patients were treated in the specified time for occlusivestenotic lesion of the iliofemoral zone, 94 of whom had blood flow disorder along the femoral and popliteal arterial bed. At the time of primary surgery, 228 patients were diagnosed with chronic arterial insufficiency (CAl) degree IIIA (according to the Fontaine R. classification, taking into account the criteria of the European Working Group (1992)), in 189 - KhKINC IIB-IV degree, in 98 CAl degree IIB. 92 (17.6\%) patients were diagnosed with hemodynamically significant stenosis of the extracranial arteries, 75 of them patients underwent surgery on the vessels of the neck in the conditions of surgical treatment of atherosclerotic lesions of the aorto/iliofemoral-popliteal arterial area. 
Результати. У 78 пацієнтів із рецидивом хронічноі артеріальної недостатності нижніх кінцівок у віддаленому післяопераційному періоді повторне оперативне втручання здійснювали з урахуванням особливостей первинної реваскуляризації артеріального русла, локалізації стенотично оклюзивного процесу, його поєднання та поширення атеросклеротичного процесу. Повторна реваскуляризація ускладнилася розвитком тромбозу сегмента реконструкції (10 випадків, що становить 12,8 \% спостережень).

Висновки. Основним реваскулярним втручанням у пацієнтів із рецидивом хронічної артеріальної недостатності є нестандартні, технічно складні, багаторівневі решунтуючі операції. При реваскуляризації гомілкового артеріального сегмента використовували стегно/підколінно-гомілкове аутовенозне шунтування та ендоваскулярну ангіопластику.

Ключові слова: реваскуляризація артеріального русла; облітеруючий атеросклероз; хронічна артеріальна недостатність; повторна реваскуляризація.

\section{ВСТУП}

Недивлячись на сучасні досягнення у судинній хірургії, згідно із дослідженнями деяких авторів, частота порушень прохідності реконструйованих артерій залишається високою $[1,2]$. За даними В. А. Губки [3], ускладнення пізнього післяопераційного періоду спостерігали у 7,9 - 34,1 \% пацієнтів. Основною причиною розвитку ускладнень пізнього післяопераційного періоду в них після реконструктивних втручань на магістральних артеріях нижніх кінцівок за даними А. Б. Доміняка та M. S. Conte [4, 5] вважають прогресування некорегованого атеросклеротичного процесу. До найчастіших ускладнень віддаленого післяопераційного періоду відносять тромбози артерій та шунтів, несправжні аневризми анастомозів, інфекційні ускладнення із поширенням процесу на судинні експлантати [6, 7]. Поряд з цим діагностують ряд віддалених ускладнень, що пов'язані 3 прогресуванням некорегованого атеросклеротичного процесу і сприяють розвитку ускладнень, серед яких розвиток реперфрузійно-реоксигенаційного синдрому [8, 9].

Метою дослідження було покращити результати повторної реваскуляризації артеріального русла нижніх кінцівок у пацієнтів із рецидивом хронічної артеріальної недостатності у віддаленому післяопераційному періоді після реконструкції аорто/клубово-стегнової зони.

\section{МАТЕРІАЛИ I МЕТОДИ}

Протягом 2006-2019 рр. простежено віддалені результати хірургічного лікування 522 хворих. Оперативне втручання проведено 353 пацієнтам із атеросклеротичною оклюзією аорто-стегнової зони, з яких у 260 мало місце порушення кровотоку
Results. In 78 patients with recurrent chronic arterial insufficiency of the lower extremities in the distant postoperative period, re-operative intervention was performed taking into account the features of primary revascularization of the arterial bed, localization of the stenotically occlusive process, its combination and the prevalence of atherosclerotic. Re-revascularization was complicated by the development of the thrombosis of the reconstruction segment (10 cases, representing $12.8 \%$ of observations).

Conclusions. Non-standard, technically sophisticated, multilevel surgery is the major revascularizing intervention in patients with relapsed chronic arterial insufficiency. For revascularization of the tibial arterial segment, thigh/ popliteal and tibial autovenous bypass was used and endovascular balloon angioplasty was used.

Key words: revascularization of the arterial vessel; obliterating atherosclerosis; chronic arterial insufficiency; repeated revascularization.

по стегно-підколінному сегменті. У вказані терміни прооперовано 159 пацієнтів з приводу оклюзивностенотичного ураження клубово-стегнового зони, 3 яких у 94 мало місце порушення кровоплину по стегно-підколінному артеріальному руслі. На час первинного хірургічного втручання у 228 пацієнтів діагностовано хронічну артеріальну недостатність (XАН) IIIA ст. (за класифрікацією R. Fontaine 3 урахуванням критеріїв Європейської робочої групи (1992)), у 189 - ХКІНК ІІІБ-IV ст., у 98 - ХАН ІІБ ст. У 92 (17,6 \%) хворих був гемодинамічно значимий стеноз екстракраніальних артерій, з них 75 проведено оперативне втручання на судинах шиї в умовах хірургічного лікування атеросклеротичного ураження аорто/клубово-стегно-підколінного артеріального русла.

У віддаленому післяопераційному періоді в оперованих пацієнтів діагностовано 146 (27,97 \%) пізніх ускладнень, з яких 5 (3,42 \%) інфарктів міокарда, 2 (1,38 \%) гострих порушень мозкового кровобігу та 139 (95,10 \%) ускладнень аорто/клубово-стегнової зони. Із них у 42 (30,2 \%) пацієнтів розвинувся пізній тромбоз однієї із бранш аорто/клубово-біфеморального алопротеза та пізній тромбоз клубовостегнового сегмента контрлатеральної нижньої кінцівки, у 11 (7,9 \%) хворих діагностовано несправжні аневризми дистального та проксимального анастомозів аорто/клубово-біфеморального алошунта, у 8 (5,8 \%) - пізні інфрекційні ускладнення у вигляді нориці ділянки дистального анастомозу, в 78 (56,1 \%) встановлено рецидив хронічної артеріальної недостатності нижніх кінцівок (ХАН ІІБ та ХАН ІІІА ст. (за класифрікацією R. Fontaine з урахуванням критеріїв Європейської робочої групи (1992)).

При аналізі первинних оперативних втручань виділено три групи пацієнтів. В основу розподі- 
лу покладено поширеність атеросклеротичного ураження магістрального артеріального русла нижніх кінцівок та об'єм первинної реконструкції аорто/клубово-стегново-підколінного артеріальної зони. В першу групу увійшли 22 спостереження (первинна операція) - реконструкція аорто/клубово-стегнової зони за відсутності гемодинамічно значимого атеросклеротичного ураження інорраінгвінального артеріального русла нижньої кінцівки. Друга група (43 спостереження, первинна операція) - реконструкція аорто/клубово-стегнової зони при наявності стенотично-оклюзивного процесу поверхневої артерії стегна (ПАС). Третя група (13 спостережень, первинна операція) - реконструкція аорто/клубово-стегнової зони, яку доповнили аутовенозним стегно-дистальним шунтуванням.

Стенотично-оклюзивний атеросклеротичний процес у пацієнтів першої групи виявлено через $(6,2 \pm 1,9)$ року після проведення первинної реваскуляризації аорто/клубово-стегнового артеріального русла. При ультрасонографрічному та ангіотомографрічному обстеженнях у хворих у віддаленому післяопераційному періоді діагностовано наступні стенотично-оклюзивні процеси стегно-дистального артеріального русла: критичний стеноз дистального анастомозу із втягненням у процес глибокої артерії стегна (ГАС) (стеноз гирла до 50-65 \%), стенотично-оклюзивний процес поверхневої артерії стегна (ПАС) - 7 спостережень; стенотичнооклюзивний процес ПАС і підколінної артерії (ПА) - 10 та стенотично-оклюзивний процес гомілкових артерій у 5 пацієнтів; гемодинамічно незначний стенозуючий процес стегно-підколінного сегмента та стенотично-оклюзивний процес гомілкових артерій - 5 спостереження.

Стенотично-оклюзивний атеросклеротичний процес у пацієнтів другої групи виявлено через $(5,4 \pm 1,3)$ року після первинної реваскуляризації аорто/клубово-стегново-підколінного артеріального русла. При ультрасонографрічному та ангіотомографічному обстеженнях у віддаленому післяопераційному періоді діагностовано наступні стенотично-оклюзивні процеси магістрального артеріального русла нижніх кінцівок: критичне стенозування дистального анастомозу А/K-C протеза із стенозом гирла (60-70\%) ГАС та стенотично-оклюзивний процес гомілкових артерій - 11 спостережень; критичне стенозування дистального анастомозу A/K-С протеза із стенозом гирла (55-70 \%) ГАС, поширення оклюзії ПАС на ПА та стенотично-оклюзивний процес гомілкових артерій - 14 спостережень; поширення атеросклеротичної оклюзії ПАС на ПА та стенотично-оклюзивний процес гомілкових артерій - 13 спостережень; критичний стеноз ПА та стенотично-оклюзивний процес гомілкових артерій - 5 спостережень.
Стенотично-оклюзивний атеросклеротичний процес у пацієнтів третьої групи виявлено через $(4,1 \pm 1,6)$ року після проведення первинної реваскуляризації аорто/клубово-стегново-підколінного артеріального русла. При ультрасонографрічному та ангіотомографрічному обстеженнях у віддаленому післяопераційному періоді діагностовано наступні стенотично-оклюзивні процеси інфраінгвінального артеріального русла: несправжня аневризма дистального A/K-C анастомозу та оклюзія стегно-дистального аутовенозного шунта - 1 спостереження; критичний стеноз дистального аорто/клубово-стегнового анастомозу із втягненням у процес гирла ГАС та оклюзія стегно-дистального аутовенозного шунта (до колінної щілини - 3, нижче колінної щілини - 1) - 4 спостереження; оклюзія стегно-дистального аутовенозного шунта (до колінної щілини - 3, дистальний анастомоз із підколінною артерією - 5) та стенотично-оклюзивний процес гомілкових артерій - 8 спостережень.

\section{РЕЗУЛЬТАТИ ТА ОБГОВОРЕННЯ}

У 78 пацієнтів із рецидивом хронічної артеріальної недостатності нижніх кінцівок у віддаленому післяопераційному періоді повторне оперативне втручання здійснювали з урахуванням особливостей первинної реваскуляризації артеріального русла, локалізації стенотично оклюзійного процесу, його поєднання та поширеності атеросклеротичного процесу $[10,11]$.

У пацієнтів першої групи, в яких первинну реваскуляризацію аорто/клубово-стегнового артеріального русла було виконано за відсутності гемодинамічно значимого атеросклеротичного ураження стегно-дистального артеріального русла, при критичному стенозі дистального анастомозу (ДА) аорто/клубово-стегнового алопротеза із втягненням у процесі ГАС (стеноз гирла 50$65 \%)$ і стенотично-оклюзивному процес ПАС (7 спостережень) виконали повну резекцію ДА (2 спостереження), а в 5 обмежились виключенням ДА без повного його виділення із наступним алопротезуванням. При алопротезуванні проксимальний анастомоз фрормували із дистальним сегментом аорто/клубово-стегнового алопротеза, а дистальний - кінець в бік нижньої третини ПАС або ПА. В усіх спостереженнях проводили фрормування анастомозу гирла ГАС із алопротезом.

У пацієнтів при стенотично-оклюзивному процесі ПАС та ПА (10 спостережень) і втягненні у процес гомілкового артеріального русла (5 спостережень) проведено стегно-дистальне алошунтування (6 спостережень), аутовенозне шунтування (4 спостереження). Проксимальний анастомоз орормували на рівні ДА аорто/клубово-стегнового алопротеза, дистальний - із ПАС до щілини ко-
Вісник медичних і біологічних досліджень Bulletin of Medical and Biological Research
1,2019 
лінного суглоба (2 спостереження) і на рівні ПА (8 спостережень). У 5 випадках операції доповнені ендоваскулярною балонною ангіопластикою гомілкових артерій (у 3 випадках ендоваскулярна балонна ангіопластика двох артерій гомілки, в одному випадку ендоваскулярна балонна ангіопластика тибіоперинеального стовбура, в одному випадку ендоваскулярна балонна ангіопластика ЗВГА) $[12,13]$.

При гемодинамічно незначимому стенозі стегно-підколінного сегмента та стенотично-оклюзійному процесі гомілкових артерій (5 спостережень) у двох пацієнтів проведено підколінно - ЗВГА аутовенозне шунтування, а в інших 3 здійснено ендоваскулярну балонну ангіопластику (балонна ангіопластика тібіопенеального стовбура і ПВГА або ЗВГА - 2 спостереження, балонна ангіопластика ЗВГА - 1 спостереження).

У пацієнтів другої групи, у яких первинну реваскуляризацію аорто/клубово-стегнового артеріального русла було виконано при наявності стенотично-оклюзивного процесу ПАС, при критичному стенозуванні ДА аорто/клубово-стегнового протеза із стенозом гирла ГАС (60-70 \%) та стенотично-оклюзивному процесі гомілкових артерій (11 спостережень) проводили повну резекцію ДА (4 спостереження), а у 7 обмежились виключенням ДА без повного його виділення із наступним алопротезуванням. При алопротезуванні проксимальний анастомоз фформували із дистальним сегментом ДА аорто/клубово-стегнового протеза, а дистальний - кінець в бік на рівні нижньої третини ПАС (4 випадки) та на рівні ПА (7 випадків). У всіх спостереженнях фрормували анастомоз гирла ГАС із алопротезом. У 5 спостереженнях здійснено підколінно - ЗВГА аутовенозне шунтування, у 6 ендоваскулярну балонну ангіопластику гомілкових артерій (у 4 випадках ендоваскулярну балонну ангіопластику двох артерії гомілки)[14].

При критичному стенозуванні ДА аорто/клубово-стегнового протеза із стенозом гирла ГАС (55-70\%), поширенні оклюзії ПАС на ПА та стенотично-оклюзивному процесі гомілкових артерій (14 спостережень) обмежились виключенням ДА без повного його виділення із наступним алопротезуванням. При алопротезуванні проксимальний анастомоз формували із дистальним сегментом аорто/клубово-стегнового протеза, а дистальний кінець анастомозували із ПА. У всіх спостереженнях здійснювали ендартеректомію із ПА й анастомозування ГАС у бік алопротеза. У 5 спостереженнях здійснено підколінно - ЗВГА аутовенозне шунтування, в одному - підколінно - ПВГА аутовенозне шунтування, у 8 - ендоваскулярну балонну ангіопластику гомілкових артерій (у 5 випадках ендоваскулярна балонна ангіопластика двох артерії гомілки, в одному спостереженні ендоваскулярна балонна ангіопластика тібіоперинеального стовбура і ПВГА, у 2 випадках ендоваскулярна балонна ангіопластика ЗВГА або ПВГА).

При поширенні атеросклеротичної оклюзії ПАС на ПА та стенотично-оклюзивному процесі гомілкових артерій (13 спостережень) здійснювали алопротезування, при якому проксимальний анастомоз фрормували із ДА аорто/клубово-стегнового протеза, а дистальний - на рівні ПА. У всіх спостереженнях перед фрормуванням дистального анастомозу здійснювали ендартеректомію із ПА. У 4 спостереженнях проведено підколінно - ЗВГА аутовенозне шунтування, у двох - підколінно - ПВГА аутовенозне шунтування, у 7 - ендоваскулярну балонну ангіопластику гомілкових артерій (у 4 випадках ендоваскулярна балонна ангіопластика по дві артерії гомілки).

При критичному стенозі ПАС і ПА та стенотично-оклюзивному процесі гомілкових артерій (5 випадків) здійснювали алопротезування (4 спостереження), аутовенозне шунтування (1 спостереження), при якому проксимальний анастомоз фрормували із ДА аорто/клубово-стегнового протеза, а дистальний - на рівні ПА. Перед фрормуванням дистального анастомозу проводили ендартеректомію із ПА. У 2 спостереженнях здійснено підколінно - ЗВГА аутовенозне шунтування, в одному - підколінно - ПВГА аутовенозне шунтування, у 2 ендоваскулярну балонну ангіопластику гомілкових артерій (ендоваскулярна балонна ангіопластика двох артерій гомілки).

У пацієнтів третьої групи, у яких первинна реконструкція аорто/клубово-стегнової зони доповнена аутовенозним стегно-дистальним шунтуванням, у віддаленому післяопераційному періоді діагностовано несправжню аневризму дистального А/К-С анастомозу та оклюзію стегно-дистального аутовенозного шунта (1 випадок). У наведеному спостереженні здійснено повну резекцію аневризми ДА А/К-С, відсічено ГАС на рівні її гирла. При алопротезуванні проксимальний анастомоз сорормований із дистальним сегментом A/К-С алопротеза за типом кінець-в-кінець, а дистальний - кінець алопротеза у бік ПА. Потрібно вказати, що дистальну 1/3 частину протеза замінено аутовеною. Відновлення кровобігу по ГАС здійснено шляхом вшивання гирла ГАС у бік алопротеза.

При критичному стенозі ДА А/К-С протеза із втягненням у процес гирла ГАС та оклюзії стегно-дистального аутовенозного шунта (4 спостереження) виконали повну резекцію ДА (1 спостереження), а у 3 обмежились виключенням ДА без повного його виділення із наступним алопротезуванням. При алопротезуванні проксимальний анастомоз фрормували за типом кінець алопротеза 
в бік дистального первинного анастомозу первинного алопротеза, а дистальний - кінець алопротеза у бік ПА. Дистальну 1/3 частину алопротеза замінювали аутовеною. Відновлення кровобігу по ГАС здійснювали шляхом анастомозування гирла ГАС у бік алопротеза (3 спостереження) [15].

При оклюзії стегно-дистального аутовенозного шунта та стенотично-оклюзивному процесі гомілкових артерій (8 спостережень) здійснювали стегно-дистальне реаутовенозне шунтування (2 випадки), реалошунтування (1 випадок), тромбектомію із аутовенозного шунта із відновленням функції анастомозів (1 проксимальний, 4 дистальних). Наведені оперативні втручання доповнювали: в 1 спостереженні проведенням підколінно - ЗВГА аутовенозним шунтування, у двох - підколінно - ПВГА аутовенозним шунтуванням, у 3 - ендоваскулярною балонною ангіопластикою гомілкових артерій (у 2 випадках ендоваскулярна балонна ангіопластика двох артерії гомілки). У двох спостереженнях не було можливості здійснити реваскуляризацію гомілкового сегмента, що й було причиною проведення операції непрямої реваскуляризації РОТ (реваскуляризуюча трепанація великогомілкової кістки).

Післяопераційний період у 10 (12,8 \%) пацієнтів ускладнився тромбозом сегмента реконструкції. Тромбоз стегно-дистального аутовенозного шунта (4 спостереження) розвинувся в умовах формування анастомозу із гомілковими артеріями. В двох спостереженнях тромбоз розвинувся після ендоваскулярної балонної ангіопластики гомілкових артерій. В одному випадку тромбоз стегно-дистального аутовенозного шунта сфрормувався із-за компресії останнього на рівні підколінної ямки. Післяопераційний тромбоз реалопротеза розвинувся на рівні анастомозування гирла ГАС із останнім (1 спостереження).

У вищенаведених 5 спостереженнях вдалось ліквідувати тромбоз сегмента реконструкції. В одному випадку спроби ліквідувати тромбоз сегмента реконструкції було невдалими, подібне спостерігалось у пацієнта після виконання ендоваскулярної балонної ангіопластики гомілкової артерії.

У двох пацієнтів розвинувся тромбоз стегнодистального реаутовенозного шунта. Це спостереження, у яких не було можливості провести реваскуляризуюче оперативне втручання на гомілкових артеріях, а було здійснено тільки РОТ.

Прогресування атеросклеротичного процесу в пацієнтів після реваскуляризації аорто/клубовостегно-підколінної артеріальної зони - основна причина формування хронічної артеріальної недостатності. При цьому спостерігають системне ураження артеріальної системи. Але особливою мішенню атеросклеротичного ураження $€$ місцях травматизації артеріального русла (анастомози ендартеректомія) та гомілкове артеріальне русло. Подібне спостерігається у пацієнтів, які в минулому перенесли багаторівневу реваскуляризацію магістрального артеріального русла. У них терміни формування рецидиву хронічної артеріальної недостатності після реконструктивних втручань на аорто/клубово-стегно-підколінній артеріальній зоні на 2,8 року коротші, ніж в інших пацієнтів.

Багатоповерховість атеросклеротичного ураження артеріального русла нижніх кінцівок, рубцеві зміни після первинної реваскуляризації, прогресуюче атеросклеротичне ураження шляхів відтоку створюють технічні складнощі при повторній реваскуляризації. Найпоширенішим хірургічним втручанням у вказаних умовах $€$ решунтуючі операції, які можуть охоплювати декілька артеріальних сегментів. Останні нестандартні, технічно складні при виконанні й завжди при таких ситуаціях постає питання відновлення кровотоку по гомілковому артеріальному руслі. Крім проведення стегно/підколінно-гомілкових аутовенозних шунтувань ендоваскулярна балонна ангіопластика $€$ тією хірургічною маніпуляцією, яка дозволяє в ряді випадків успішно завершити реваскуляризацію гомілкового сегмента.

Післяопераційний період у 10 (12,8 \%) пацієнтів ускладнився тромбозом сегмента реконструкції. Тромбоз стегно-дистального аутовенозного шунта (4 спостереження) розвинувся в умовах формування анастомозу із гомілковими артеріями. У двох спостереженнях тромбоз стегно-дистального реаутовенозного шунта розвинувся в результаті відсутньої можливості провести реваскуляризуюче оперативне втручання на гомілкових артеріях, а було здійснено тільки РОТ. У 5 спостереженнях вдалось ліквідувати тромбоз сегмента реконструкції.

Підсумовуючи викладений матеріал, можна вказати, що в результаті прогресування атеросклеротичного процесу більшою мірою вражаються сегменти попередньої травматизації артеріального русла та гомілкові судини. Саме наведені зони інтенсивного прогресування атеросклеротичного процесу фрормують розвиток рецидиву хронічної артеріальної недостатності. Повторну реваскуляризацію артеріального русла при рецидиві хронічної артеріальної недостатності здійснюють в умовах рубцево змінених тканинах, основою якої являються решунтуючі операції, які охоплюють декілька сегментів, із обов'язковою реваскуляризацією шляхів відтоку - гомілкового артеріального русла. При цьому було виконано стегно/підколінно-гомілкове аутовенозне шунтування (19 спостережень) та ендоваскулярну балонну ангіопластику (30 спостережень).
Вісник медичних і біологічних досліджень Bulletin of Medical and Biological Research
1,2019 


\section{ВИСНовкИ}

1. При повторній реваскуляризації артеріального русла у пацієнтів із рецидивом хронічної артеріальної недостатності після реконструкції аорто/клубово-стегнової зони основним хірургічним втручанням були решунтуючі операції інфрраінгвінальної артері- альної зони із обов'язковою реваскуляризацією шляхів відтоку - гомілкового артеріального русла.

2. При реваскуляризації шляхів відтоку - гомілкового артеріального русла крім стегно/підколінногомілкового аутовенозного шунтування застосовувати ендоваскулярну ангіопластику.

\section{СПИСОК ЛІТЕРАТУРИ}

1. Кобза І. І. Повторні реконструкції з приводу інфрікування синтетичних судинних протезів: вибір аутовенозного матеріалу / І. І. Кобза, Р. А. Жук, Я. І. Ярема // Вісник невідкладної і відновної медицини. - 2010. - № 11. С. $521-523$.

2. Кобза І. І. Хірургічне лікування пацієнтів при інсрікуванні судинних протезів аорто-стегнової зони / І. І. Кобза, Т. Г. Сорока, Р. А. Жук // Клінічна хірургія. 2004. - № 4-5. - C. 89-90.

3. Губка В. А. Хирургическое лечение осложнений операций у больных облитерирующим атерослерозом аорты и артерий нижних конечностей / В. А. Губка // Патологія. - 2012. - № 1. - С. 89-91.

4. Повторні реконструктивні втручання на черевній частині аорти та периореричних артеріях / А. Б. Доміняк, Ю. Л. Ящук, Г. Г. Влайков, А. В. Ратушняк // Серце і судини. - 2005. - №1. - С. 56-57.

5. Conte M. S. Critical appraisal of surgical revascularization for critical limb ischemia / M. S. Conte // Journal of Vascular Surgery. - 2013. - Vol. 57. - P. 8S - 13 S.

6. Диденко Ю. П. Причины выполнения повторных оперативных вмешательств в отдаленные сроки после реконструктивных операций на артериях нижних конечностей у больных с облитерирующим атеросклерозом / Ю. П. Диденко, Г. Н. Горбунов // Вестник СанктПетербургского университета. - 2008. - Серия 1. Вып. 1. - С. 71-76.

7. Results of Infrapopliteal Endovascular Procedures Performed in Diabetic Patients with Critical Limb Ischemia and Tissue Loss from the Perspective of an Angiosome-Oriented Revascularization Strategy / F. Acun, C.Varela, I. Lopez de Maturana [et al.] // International Journal of Vascular Medicine. - 2014. - Vol 3. - P. 1 - 13

8. Белов Ю. В. Повторные реконструктивные операции на аорте и магистральных артериях / Ю. В. Белов,

\section{REFERENCES}

1. Kobza II, Zhuk RA, Yarema Yal. [Repeated reconstructions for the infection of synthetic vascular prostheses: the choice of autogenous material]. Visn nevidkl i vidnovn med. 2010;11: 521-3. Ukrainian.

2. Kobza II, Soroka TH, Zhuk RA. [Surgical treatment of patients with infection of the aortic-femoral vascular prostheses]. Klin khir. 2004;4-5: 89-90. Ukrainian.

3. Hubka VA. [Surgical treatment of advanced operations in large forms of aortic atherosclerosis and lower extremity arteries]. Patolohiia. 2012;1: 89-91 [in Ukrainian].

4.DominiakAB, YashchukYuL, VlaikovHH, RatushniakAV. [Repeated reconstructive interventions on the abdominal
А. Б. Степаненко. - М. : Мед. информ. агентство, 2009. $-174 \mathrm{c}$.

9. Русин В. І. Повторні реконструктивні операції при реоклюзії судин стегново-подколінно-тібіального сегмента / В. І. Русин, В.В.Корсак, Ю.А.Левчан // Клінічна хірургія. - 2004. - № 4-5. - С. 104-105.

10. Гощинський В. Б. Про ефективність різних методів ендоваскулярної реваскуляризації при хронічній ішемії нижніх кінцівок / В. Б. Гощинський, О. Б. Луговий, В. В. Ольховик // Шпитальна хірургія = Госпитальная хирургия = Hospital Surgery : Український науково-практичний журнал. - 2015. - № 4. - С. 26-30.

11. Дзюба Д. О. Варіанти періопераційного знеболюванняхворихізкритичноюішемієюнижніхкінцівок, щопрооперовані методом ендоваскулярної балонопластики / Д. О. Дзюба, С. М. Недашківський, О.М.Злочевський // Медицина неотложных состояний = Медицина невідкладних станів: Специализированный научно-практический журнал. - 2016. - № 3. - С. 72-74.

12. Русин В. В. Гібридні операції з приводу критичної ішемії тканин нижніх кінцівок / В.В.Русин // Клінічна хірургія. - 2013. - № 9. - С. 42-46.

13. Femoropopliteal balloon angioplasty vs. bypass surgery for CLI: a propensity score analysis / M. Korhonen, F. Biancari, M. Soderstrom [et al.] // Eur. J. Vasc. Endovasc. Surg. - 2011. - Vol. 41, No. 3. - P. 378 - 384.

14. Гудз О. І. Можливості неінвазивної діагностики стану дистального артеріального русла у пацієнтів із хронічною критичною ішемією нижніх кінцівок / О.І.Гудз, І. М. Гудз // Серце і судини: Український науково-практичний журнал. - 2012. - № 2. - С. 112-116.

15. Ендоваскулярні втручання при критичній ішемії нижніх кінцівок / В. І. Русин [та ін.] // Клінічна анатомія та оперативна хірургія: науково практичний медичний журнал. - 2014. - Т. 13, № 2. - С. 66-68.

aorta and peripheral arteries]. Sertse i sud. 2005;1: 56-57 [in Ukrainian].

5. Conte MS. Critical appraisal of surgical revascularization for critical limb ischemia. Journ of Vasc Surg. 2013;57: 8-13.

6. Dydenko YuP, Horbunov HN. [Reasons for performing repeated surgery in the long term after reconstructive surgery on the arteries of the lower extremities in patients with obliterating atherosclerosis]. Vestn Sankt-Peterbur unyv. 2008; 1(1): 71 - 76 [in Russian].

7. Acun F, Varela C, Lopez de Maturana I. Results of infrapopliteal endovascular procedures performed in diabetic 
patients with critical limb ischemia and tissue loss from the perspective of an angiosome-oriented revascularization strategy. Int J of Vasc Med. 2014;3: 1-13.

8. Belov YuV, Stepanenko AB. [Repeated reconstructive operations on the aorta and main arteries]. Med inform agentstvo. Moscow; 2009. Russian.

9. Rusyn VI, Korsak VV, Levchan YuA. [Repeated reconstructive operations at reocclusion of vessels of the femur-popliteal-tibial segment]. Klin khir. 2004;4-5: 104-5 [in Ukrainian].

10. Hoshchynskyi VB, Luhovyi OB, Olkhovyk VV. [About efficiency of different methods of endovascular revascularization at the chronic ischemia of lower extremities]. Shpyt khir: Ukr naukovo-prakt zhurn. 2015;4: 26-30 [in Ukrainian].

11. Dziuba DO, Nedashkivskyi SM, Zlochevskyi OM. [Variants of the perioperating anaesthetizing of patients are with the critical ischemia of lower extremities which are operated by the method of endovascular operation]. Medyts nevidkl stan: Spetsializ naukovo-prakt zhurn. 2016;3: 72-4. Ukrainian.

12. Rusyn VV. [Hybrid surgery for critical lower limb tissue ischemia]. Klin khir: Naukovo-prakt zhurn. 2013;9: 42-6. Ukrainian.

13. Korhonen $M$, Biancari $F$, Soderstrom $M$. Femoropopliteal balloon angioplasty vs. bypass surgery for CLI: a propensity score analysis. Eur J Vasc and Endovasc Surg. 2011;41(3): 378-84.

14. Hudz OI, Hudz IM. [Possibilities of non-invasive diagnosis of distal arterial status in patients with chronic critical lower limb ischemia] Sertse i sud: Ukr naukovo-prakt zhurn. 2012;2: 112-6 [in Ukrainian].

15. Rusyn VI. [Endovascular interventions for critical lower limb ischemia]. Klin anat ta oper khir: naukovo-prakt med zhurn. 2014;13(2): 66-8 [in Ukrainian].

Отримано 05.09.19 